\title{
THE RULE OF CAPTURE: \\ ITS CURRENT STATUS AND SOME ISSUES TO CONSIDER
}

\author{
CeCILIA A. LOW*
}

This article discusses the current status of the rule of capture in Canada. Briefly stated, if Party A digs for resources on their own land and captures oil or natural gas that have migrated from Party B's lands, the rule of capture allows Party A to reap the benefits of their efforts as the inconvenience to the neighbour cannot support a cause of action. The author begins by examining the historical origins of the rule throughout the English common law, then examines the current status of the rule by analyzing various legislation and regulations dealing with capture in several Canadian jurisdictions. Due to the large amount of economic and physical waste created by the race to drill numerous wells in order to capture resources as quickly as possible current Canadian legislation has somewhat modified the rule of capture and has created correlative rights, varying from jurisdiction to jurisdiction. Correlative rights create a more equitable solution to allow each owner the opportunity to share in oil or gas from a single pool extending under their properties.
Cet article porte sur l'état actuel de la règle du droit de prise au Canada. En deux mots, si Partie A creuse pour trouver des ressources sur sa propre terre et trouve du pétrole ou du gaz naturel qui a migré des terres de Partie B, la règle du droit de prise permet à Partie A de récolter les avantages pour son effort étant donné que les inconvénients pour le voisin ne peuvent soutenir une cause. L'auteur commence par examiner les origines historiques de la règle dans la common law anglaise, puis examine l'état actuel de la règle en analysant diverses lois et divers règlements ayant trait au droit de prise dans divers ressorts canadiens. En raison de la grande quantité de déchets économiques et physiques créés par la course au forage de nombreux puits afin de trouver les ressources aussi rapidement que possible, la loi canadienne en vigueur a quelque peu modifié la règle du droit de prise et a créé des droits réciproques, variant d'un ressort à un autre. Les droits réciproques créent une solution plus équitable permettant à chaque propriétaire de partager le pétrole et le gaz naturel à partir d'un seul bassin situé sous leurs propriétés.

\section{TABLE OF CONTENTS}

I. INTRODUCTION . . . . . . . . . . . . . . . . . . . . . . . . 799

II. BRief History OF THE RUle Of CAPTURE . . . . . . . . . . . . . . . . . . . 801

III. The ApPlication OF THE RULE OF CAPTURE

IN OIL AND GAS LAW IN CANAdA $\ldots \ldots \ldots \ldots \ldots \ldots \ldots \ldots \ldots \ldots$

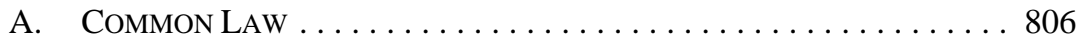

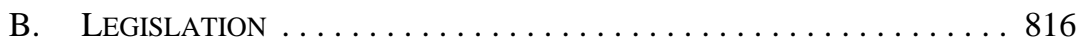

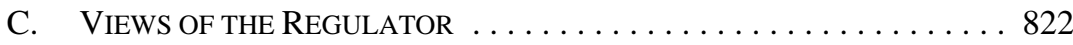

D. CuRrent State of THE Rule of

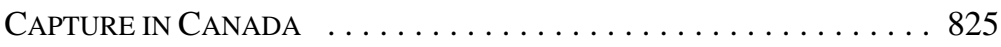

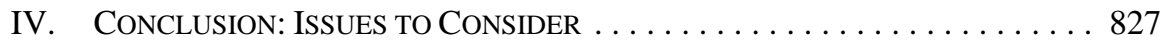

\section{INTRODUCTION}

The purpose of this article is to assess the current state and role of the rule of capture in Canadian oil and gas law. ${ }^{1}$ Briefly stated, the traditional rule of capture in oil and gas law provides that in the event A drills a well on his own land ${ }^{2}$ and produces oil or gas in a manner

Sole Practitioner, Calgary, Alberta; LL.M. student, University of Calgary. The author would like to thank Nigel Bankes for his helpful comments on the drafts of this article. Any errors are the sole responsibility of the author.

1 Onshore only.

$2 \quad$ Whether owned by A or held by A with the owner's authorization. 
consistent with good industry practice, then if some of that oil or gas originates from under neighbouring lands, A becomes the owner of the oil or gas so produced and is not liable to his or her neighbour.

The rule of capture is a common law principle rooted in the early law relating to groundwater and ferae naturae. It developed as a no liability rule in situations where the object of dispute was an unconfined, percolating, or wild thing, the behaviour of which was not well understood and which was not easily subject to application of traditional property law principles.

The rule of capture was first raised in an oil and gas law context in Canada in the case of Borys v. C.P.R. ${ }^{3}$ The case was ultimately decided by the Privy Council and while the rule of capture was not necessary to the decision, Lord Porter provided a useful description of the traditional rule of capture case in oil and gas when he said:

\footnotetext{
The petroleum, in so far as is material to the present case, is found in a bed of porous rock underlying the plaintiff's land and the surrounding property, which contains at the bottom water, then the petroleum and on top a layer of gas.... The substances are fugacious and are not stable within the container although they cannot escape from it. If any of the three substances is withdrawn from a portion of the property which does not belong to the appellant but lies within the same container and any oil or gas situated in his property thereby filters from it to the surrounding lands, admittedly he has no remedy. So, also, if any substance is withdrawn from his property, thereby causing any fugacious matter to enter his land, the surrounding owners have no remedy against him. The only safeguard is to be the first to get to work, in which case, those who make the recovery become owners of the material which they withdraw from any well which is situated on their property or from which they have the authority to draw. ${ }^{4}$
}

Application of the rule of capture to the nascent and booming oil and gas industry in the United States in the late nineteenth century resulted in a race to produce. The race caused many problems. Two of the more serious problems were over-drilling ${ }^{5}$ and the early depletion of the inherent reservoir energy necessary to maximize primary production with the result that much oil and gas was rendered unrecoverable and, therefore, wasted. ${ }^{6}$ State legislatures moved to address the problems created by the rule of capture by enacting conservation legislation directed at ameliorating the undesirable consequences of its application. ${ }^{7}$ With the benefit of the American experience, petroleum producing provinces in Canada adopted legislation which had the effect of mitigating the undesirable effects of the rule of capture from the early days of the regulation of the industry. ${ }^{8}$

The rule of capture in the oil and gas context has been the subject of some, but not extensive, judicial consideration in Canada. Similarly, there is only a small body of literature

[1953] 2 D.L.R. 65 (P.C.) [Borys].

Ibid. at 67-68.

The drilling of more wells than necessary to produce the volumes of oil and gas actually produced. Bruce M. Kramer \& Owen L. Anderson, “The Rule of Capture — An Oil and Gas Perspective” (2005) 35 Envtl. L. 899 at 902.

Ibid. at 901.

David H. Breen, Alberta's Petroleum Industry and the Conservation Board (Edmonton: University of Alberta Press, 1993) at liii. 
examining the application of the rule of capture in the Canadian oil and gas context. ${ }^{9}$ In the balance of this article I will briefly examine the history of the rule of capture in the oil and gas law context, assess the status of the rule in Canadian oil and gas law and finally, consider issues raised by the application of the rule of capture in all instances.

\section{BRIEF HISTORY OF THE RULE OF CAPTURE}

The rule of capture is variously described and applied as both an ownership theory and a no liability rule. The common law rule of capture, as it is applied in Canadian oil and gas law, is said to have its roots in the English groundwater case of Acton v. Blundell ${ }^{10}$ where the court said:

[T]hat the person who owns the surface may dig therein, and apply all that is there found to his own purposes at his free will and pleasure; and that if, in the exercise of such right, he intercepts or drains off the water collected from the underground springs in his neighbour's well, this inconvenience to his neighbour falls within the description of damnum absque injuria, which cannot become the ground of an action. ${ }^{11}$

The facts of Acton, briefly, were that the successive owners of a spinning mill, of which Acton was one, had for years, taken groundwater from a well or wells on their land for use in their business. Blundell leased neighbouring lands for the purposes of extracting coal. To that end, a series of coal pits were dug and, in the course of the mining operation, groundwater was drained from under the mill owners' lands. As a result, the water level in the mill owners' wells dropped and the wells eventually dried up. There is no indication in the case report that Blundell required or used the drained water. In Acton, the court framed the issue for decision as being: "whether the right to the enjoyment of an underground spring, or of a well supplied by such underground spring, is governed by the same rule of law as that which applies to, and regulates, a watercourse flowing on the surface.”12

If the law pertaining to surface waters had applied, the owners of the mill would have been entitled to have the waters flowing from or through the mine owner's lands to their lands and wells undiminished.

The court declined to find that the law as applied to surface watercourses should apply in the case of underground springs. The basis for the court's finding was that since no one could

See J.H. Laycraft \& Ivan L. Head, “Theories of Ownership of Oil and Gas” (1953) 31 Can. Bar Rev. 382; J.M. MacIntyre, "The Development of Oil and Gas Ownership Theory in Canada” (1969) 4 U.B.C. L. Rev. 245; J.T. Cawley, “Oil and Gas Conservation in Saskatchewan” (1969) 7 Alta. L. Rev. 347; C.H. Hebb, “Common Carrier, Common Purchaser and Common Processor Orders” (1969) 7 Alta. L. Rev. 436; Richard A. Neufeld \& Robert G. Grant, "Drainage Issues in the Atlantic Canada Offshore Petroleum Industry" (2001) 24 Dal. L.J. 127; Van Penick, "Legal Framework in the Canadian Offshore” (2001) 24 Dal. L.J. 1.

(1843) 12 M. \& W. 324, 152 E.R. 1223 (Ex.) [Acton].

Ibid. at 1235.

Ibid. at 1233. That rule being: "each proprietor of the land has a right to the advantage of the stream flowing in its natural course over his land, to use the same as he pleases, for any purposes of his own, not inconsistent with a similar right in the proprietors of the land above or below; so that, neither can any proprietor above diminish the quantity or injure the quality of the water which would otherwise naturally descend" (at 1233). 
see or know the characteristics of underground waters, no one could have a sufficiently well defined interest in them to be able to prevent another person from exercising their rights of land ownership in a way that might affect those waters. ${ }^{13}$ To put it another way, what Acton decided was that a landowner has no right to retain or maintain a fugacious substance such as percolating groundwater in place under his lands. As a result, the interests of one landowner in obtaining groundwater in the course of exercising his real property rights were subordinated to the real property rights of the other. ${ }^{14}$ The Court of Exchequer Chamber employed the rule of capture as a means of justifying its allocation of entitlements between the parties.

The origins of the case law on the subject of the rule of capture as it applies to oil and gas begins in the late nineteenth and early twentieth centuries. U.S. courts adopted the rule during the early American oil boom when they were faced with a flood of litigation over ownership of oil and gas stemming from the race to cash in on the oil boom in states which had freehold oil and gas rights regimes. Unlike Acton, the early rule of capture cases in the U.S. courts were specifically about competition for the same resource.

In struggling to develop a property law theory in respect of a matter about which very little was known, the courts analogized oil and gas to flowing water and wild animals. For example, in Westmoreland \& Cambria Nat. Gas Co. v. De Witt ${ }^{15}$ the Supreme Court of Pennsylvania said:

Gas, it is true, is a mineral; but it is a mineral with peculiar attributes, which require the application of precedents arising out of ordinary mineral rights, with much more careful consideration of the principles involved than of the mere decisions. Water also is a mineral; but the decisions in ordinary cases of mining rights, etc., have never been held as unqualified precedents in regard to flowing, or even to percolating, waters. Water and oil, and still more strongly gas, may be classed by themselves, if the analogy be not too fanciful, as minerals ferae naturae. In common with animals, and unlike other minerals, they have the power and the tendency to escape, without the volition of the owner. Their "fugitive and wandering existence within the limits of a particular tract is uncertain".... They belong to the owner of the land, and are part of it, so long as they are on or in it, and are subject to his control; but when they escape, and go into other land, or come under another's control, the title of the former owner is gone. Possession of the land, therefore, is not necessarily possession of the gas. If an adjoining, or even a distant, owner, drills his own land, and taps your gas, so that it comes into his well and under his control, it is no longer yours, but his. ${ }^{16}$

$13 \quad$ Ibid. at 1234.

14 This was affirmed in the later case of Chasemore v. Richards, (1859) 7 H.L. Cas. 349, 11 E.R. 140 [Chasemore]. In Chasemore the House of Lords held that the owner of land containing water percolating underground in undefined channels, has the right to divert or appropriate such water within his own land even if the effect is to deprive his neighbour of it. The case of Bradford (Borough of) v. Pickles, [1895] 1 A.C. 587 (H.L.) reaffirmed the subordination of a landowner's interest in maintaining subterranean groundwater flow to the real property rights of a neighbouring landowner (to divert or appropriate such water within his own land), even where the latter landowner's acts were specifically designed to adversely affect his neighbour's interest.

1518 A. 724 (Sup. Ct. Pa. 1889) [De Witt].

16 Ibid. at 725. Note that this excerpt was dicta in the case but is said to be widely relied upon by U.S. courts in adopting the rule of capture in the oil and gas context. See for example, Kramer \& Anderson, supra note 6 at 906. 
Citing De Witt, the United States Supreme Court, in dicta in Brown v. Spilman, ${ }^{17}$ accepted the rule of capture as being the appropriate ownership theory for oil and gas. ${ }^{18}$

In the face of the press of litigation over oil and gas ownership, the U.S. courts seized on the rule of capture as a means of determining ownership rights in situations which simply did not fit easily, or at all, into existing property law principles. According to the Harvard Law Review:

That rule gives a well-owner indefeasible title to oil and gas produced by his well, even though drawn from under the land of his neighbors. The principle appears to have been adopted as a rule of convenience to meet the difficulties inherent in determining under whose land the gas or oil originally lay... and to relieve wellowners from the constant risk of liability for innocent conversion which a contrary rule would create.... The apparent injustice ... was considered alleviated by their opportunity to protect themselves by drilling and operating offset wells. ${ }^{19}$

While relying heavily on the rule, the courts also recognized its inherent weaknesses. For example, the relevant facts of the widely cited case of Barnard v. Monongahela Natural Gas $\mathrm{Co}^{20}$ were that Monongahela had drilled a well approximately 35 feet from a property line and the evidence established that the well's drainage area would draw 75 percent of the gas it produced from under the neighbour's land. The Pennsylvania Supreme Court identified the issue as being whether: "a landowner in gas territory, drill a well on his farm close to the line of his adjoining landowner and draw from the land of the latter three-fourths of the gas that his well may produce without so invading the property rights of the adjoining landowner as to be legally accountable therefor."21 The Court went on to say:

\footnotetext{
'The right of every landowner to drill a well on his own land at whatever spot he may see fit' certainly must be conceded. If, then, the landowner drills on his own land at such a spot as best subserves his purposes, what is the standing of the adjoining landowner whose oil or gas may be drained by this well? He certainly ought not to be allowed to stop his neighbor from developing his own farm.... What then can the neighbor do? Nothing, only go and do likewise. He must protect his own oil and gas. He knows it is wild and will run away if it finds an opening and it is his business to keep it at home. This may not be the best rule; but neither the Legislature nor our highest court has given us any better. ${ }^{22}$
}

Doing likewise became known as offset drilling and, predictably, resulted in a vast proliferation of wells and overproduction. ${ }^{23}$

Ibid. at 802 .

Ibid.

Breen, supra note 8 at xlii. In some areas, well densities were reported to be five to ten wells per acre with an astonishing 27 wells per acre in an East Texas oil field. 
It had quickly become apparent that continued reliance on the rule without modification was untenable. It resulted in significant waste ${ }^{24}$ in the race to drill, offset drill, and capture as much petroleum as possible from any given reservoir before others could do so. A striking example of the consequences of the application of the rule of capture was the "Texas spite fence” - a dense clustering of wells drilled directly abutting property lines to drain petroleum from under neighbouring lands. ${ }^{25}$

The courts, however, determined that it was not within their purview to place limits on the application of the rule to prevent waste and deferred to the legislators. ${ }^{26}$ With varying degrees of haste, each producing state enacted oil and gas conservation laws to introduce correlative rights ${ }^{27}$ and/or limits intended to mitigate the rule of capture and thereby ameliorate the waste resulting from its application. ${ }^{28}$ Legislated efforts to limit the rule of capture and to impose conservation included well spacing and pooling requirements as well as production limitations. ${ }^{29}$

Following the legislatures' lead, often in the course of upholding conservation laws that were subject to challenge in many states, the U.S. courts also incorporated correlative rights into the U.S. common law relating to the rule of capture. ${ }^{30}$ Early correlative rights cases affirmed the ability of state legislatures to impose laws aimed at preventing waste (of gas) to the injury of the public at large or to others where a possible injury was the exhaustion of a gas reservoir, whether through loss of the gas itself or through loss of reservoir energy, to the public detriment. ${ }^{31}$

While the unrestricted application of the rule of capture had harsh and unfortunate consequences in the U.S. oil and gas industry, it did and does have its supporters. For example Professor Eugene Kuntz said in support of the rule:

The person undertaking such an enterprise [the taking of financial risk to drill wells and produce oil and gas] should have some assurance that he will be permitted to enjoy the natural results of his enterprise so long as

Waste includes: physical waste, for example gas lost to flaring and unrecoverable oil and gas reserves due to early or too rapid depletion of reservoir energy, and economic waste resulting from inefficient use of resources and over drilling.

David Edward Pierce, "Coordinated Reservoir Development - An Alternative to the Rule of Capture for the Ownership and Development of Oil and Gas” (1983) 4 J. Energy L. \& Pol'y 1 at 27.

Ibid. at 33; Kramer \& Anderson, supra note 6 at 908.

The common law doctrine of correlative rights in oil and gas "limits the rule of capture by allowing each mineral owner to take only their fair share" (Cody Miller, "Petroleum Exports from Latin America to the United States” (2004) 10 Law \& Bus. Rev. Am. 819 at 823 [citations omitted]). The common law doctrine of correlative rights carries with it "the duty not to injure the source and not to commit waste from the source" (Ana Boswell Schepens, "Prospecting for Oil at the Courthouse: Recovery for Drainage Caused by Secondary Recovery Operations” (1999) 50 Ala. L. Rev. 603 at 606).

Miller, ibid.

See Kramer \& Anderson, supra note 6 at 931; Pierce, supra note 25 at 33; Thomas A. Reynolds, "Delimitation, Exploitation, and Allocation of Transboundary Oil \& Gas Deposits Between NationStates” (1995) 1 ILSA J. Int'l \& Comp. L. 135 at 139; Breen, supra note 8 at xlii.

Kramer \& Anderson, ibid.; Breen, ibid. at xli-xlii.

Kramer \& Anderson, ibid. at 912. The cases referred to in the Kramer and Anderson article may be of limited assistance outside the U.S. as they resulted from constitutional challenges to a state's authority to make laws that had the effect of limiting individual property rights. 
he does not offend some firmly established concept of property law such as the concept that land boundaries should be inviolate. ${ }^{32}$

In addition, it has been argued that

the objective of oil and gas conservation practices is not the perfect protection of correlative rights. Rather conservation practice is fundamentally utilitarian — to achieve the greatest good for the greatest number.

The rule of capture compensates for the deficiencies inherent in modern well spacing and pooling practices, the problem of relying on the fictions of homogeneous reservoirs and radial drainage, and the inaccuracies in compensatory-drainage doctrine.... [T] he rule of capture remains a central precept of modern oil and gas law, and the rule is particularly important to the efficient application of conservation laws. ${ }^{33}$

As described in the passages above, the rule of capture in U.S. oil and gas law serves as a no liability rule or the ultimate justification for allowing A to capture and deal unilaterally with oil or gas that may have been produced from B's lands, notwithstanding the fact that A located and produced his or her well strictly in accordance with applicable well spacing and production allowable laws.

The rule of capture has played a significant role in the development of U.S. oil and gas law. What about other common law jurisdictions? There has been no reported case law considering the rule of capture that this author can find in the oil and gas law context in Great Britain $^{34}$ or Australia. However, it has been suggested that the rule would apply in both jurisdictions absent legislative provisions restricting its application. ${ }^{35}$ By contrast, it seems that the rule of capture has been rejected in the oil and gas context in the Netherlands. ${ }^{36}$

In Canada, suffice it to say that by the time oil and gas exploration activity was gearing up, in Alberta in particular, Canadian policy- and law-makers had had the benefit of observing the free-for-all south of the border and the resultant waste. As a consequence, rules that had the effect of damping the effects of the rule of capture were introduced early on

Eugene Kuntz, “The Law of Capture” (1957) 10 Okla. L. Rev. 406 at 407. By contrast, see Pierce, supra note 25 at 27-33 wherein the author argues that the ongoing application of the rule of capture in U.S. oil and gas law, even in the context of conservation legislation, results in a failure to ensure rational development of oil and gas resources.

33 Kramer \& Anderson, supra note 6 at 952-54.

34 Bryan Clark, "Migratory Things on Land: Property Rights and a Law of Capture” (2002) 6.3 Electronic Journal of Comparative Law (EJCL) at 21-26, online: EJCL < http://www.ejcl.org/63/abs63-3.html>. The lack of litigation raising the issue in the oil and gas context in Great Britain and Australia is likely because of the different land and mineral ownership regimes (i.e. mineral resources, including petroleum, vested in the Crown) established in those jurisdictions.

$35 \quad$ Ibid. at 28-29. Jacqueline Lang Weaver \& David F. Asmus, "Unitizing Oil and Gas Fields Around the World: A Comparative Analysis of National Laws and Private Contracts” (2006) 28 Hous. J. Int'l. L. 3 at 49; B.M.L. Crommelin, “Queensland Oil and Gas Law,” Comment (1970-1971) 7 U.Q.L.J. 292 at 297.

$36 \quad$ Kernkamp Advocaten, “Netherlands Supreme Court rules against Rule of Capture” (14 October 2005), online: Kernkamp Advocaten <http://www.kernkamp.nl/energy_natural_resources.html>. 
through conservation legislation. ${ }^{37}$ However, waste and concerns arising from the application of the rule of capture and offset drilling were not unknown to the early Canadian oil patch. Prior to the establishment of conservation provisions, a joint federal-provincial commission established to study the Turner Valley field said the following about operators in the field: "Unless he develops his property rapidly, particularly along the boundaries, the supplies of gas and naphtha along the edges of his property can be drawn off by his adjacent neighbors. Offset drilling thus becomes a necessity to the operators and corresponding increases of wastage follow." 38

\section{THE APPLICATION OF THE RULE OF CAPTURE IN OIL AND GAS LAW IN CANADA}

\section{A. Common Law}

The case cited as confirming the role of the rule of capture in the oil and gas context in Canada, Borys, did not deal with a set of traditional rule of capture facts. ${ }^{39}$ Indeed, there has yet to be an oil and gas case in Canada where the facts squarely raise the traditional rule of capture scenario, for example, where A drills a well on lands to which he or she holds rights and produces oil or gas, some of which has migrated to A's well from under B's adjoining lands. Notwithstanding that fact, the proposition that the rule applies in the oil and gas context in Canada has been widely accepted by the courts ${ }^{40}$ as well as regulators. ${ }^{41}$ It is also generally accepted in Canadian legal literature that the common law rule of capture applies to oil and gas found in Canada. ${ }^{42}$

Borys was an appeal taken directly to the Privy Council from the Alberta Court of Appeal. Briefly, the facts in that case were that the Canadian Pacific Railway (CPR) had conveyed the estate in fee simple in certain lands in Alberta to the appellant, Mr. Borys, while reserving to itself all coal, petroleum, and valuable stone, thereby creating what are often referred to as split title lands. The CPR then leased to Imperial Oil Ltd. (Imperial) all

The early Canadian oil industry concept of conservation "involves the efficient use of natural resources, the development of these resources in such a way as to protect the interests of future generations, and the elimination of all economically avoidable waste. It may be defined as 'The preservation of natural resources for economical use.' The concept of the elimination of waste is paramount": Breen, supra note 8 at xxix, citing George Govier, "Oil and Gas Conservation" (Paper presented to the Canadian Institute of Mining and Metallurgy, Western Annual Meeting, Vancouver, 6-8 November 1950) at 1-2. Ibid. at 61, citing "Report of the Committee on the Conservation and Utilization of Waste Gas in Turner Valley Alberta" (8 January 1930) at 4.

39 See Nigel Bankes, “Pooling Agreements in Canadian Oil and Gas Law” (1995) 33 Alta. L. Rev. 493 at 497-98, n. 19 where he notes: “Under the rule of capture, B, as 'owner' of the mineral estate, is not able to restrain by injunction (or by a threat of damages action) a neighbour who is draining oil or gas from underneath B's property.... In fact, Borys does not deal with the situation of neighbouring properties, but with the competing interests of the owners of the petroleum and of the gas-cap gas."

$40 \quad$ See cases discussed in following section.

41 BP Canada Energy Company, Rateable Take, Blackstone Beaverhill Lake A Pool (February 18, 2003), AEUB Decision 2003-016, online: Energy Resources Conservation Board (ERCB) <http://www.ercb. ca/docs/documents/decisions/2003/2003-016.pdf> at 9-10 [AEUB Decision 2003-016].

$42 \quad$ See Don Greenfield \& Jay Todesco, "Fundamental Aspects of Oil and Gas Revisited” (2004) 42 Alta. L. Rev. 75; Neufeld \& Grant, supra note 9; John Bishop Ballem, The Oil and Gas Lease in Canada, 3d ed. (Toronto: University of Toronto Press, 1999) at 106; Penick, supra note 9; Bankes, supra note 39; Cawley, supra note 9 at 347; MacIntyre, supra note 9 at 265. 
petroleum that might be found under the same lands. Imperial did indeed discover a large reservoir (Leduc) underlying the lands conveyed to Borys. The reservoir was found to contain, in layers from the top down, natural gas, oil, and water. The oil layer also contained gas in solution, that is, natural gas dissolved in the oil. Producing the oil necessarily resulted in production of natural gas from the cap and also resulted in the solution gas coming out of solution (phase changing back to natural gas) as it was produced. Borys had taken no steps to exercise his rights to natural gas. ${ }^{43}$

The Court was asked to determine the following issues: what was included in the reservation of "petroleum"; and to what extent the respondent oil company was entitled to interfere with the rights Borys had to the natural gas in exercising its rights to work and win petroleum.

With respect to the first issue, the Privy Council found that the reservation of "petroleum" did not include the natural gas in situ (the gas cap) but that it did include solution gas. As a result, Borys had rights to the top layer in the reservoir but not to the solution gas, even when it came out of solution in the wellbore. With respect to the second issue, the Privy Council said:

For the purpose of their decision their Lordships are prepared to assume that the gas whilst in situ is the property of the appellant even though it has not been reduced into possession, but the question is not whose property the gas is, but what means the respondents may use to recover their petroleum. ${ }^{44}$

\section{The Privy Council went on to say:}

But the main strength of the respondents' case is that they have a direct grant of petroleum, whereas the appellant has merely such residual rights as remain in him subject to the grant to the respondents. In such circumstances their Lordships are not prepared to hold that the respondents are under an obligation to conserve the appellant's gas with the consequent denial of their right to recover the petroleum in the usual way. Even if it be conceded that the respective rights of the two parties are to work for and recover each his own property ... it does not follow that neither can act without the consent of the other and that only by mutual agreement can they work at all. ${ }^{45}$

Unlike the traditional rule of capture cases in the U.S., there was no issue in Borys of the migration of petroleum from neighbouring lands. The issue was whether Borys, as a "mere" holder of residual rights to gas could obtain an injunction to prevent Imperial from exercising its implied right to work and win the petroleum granted to it in the same lands. As it was not possible to produce the petroleum without also producing some of the gas, the case turned on the Court's interpretation of the respective rights of the parties, as evidenced by the conveyance and lease, relating to the working and winning of substances from lands belonging to Borys. 
The Alberta Court of Appeal phrased the issue as being: "It being necessary to use and interfere with the gas in the extraction of the petroleum beneath, the question is, What are the principles of law applicable to the respective positions of the parties?"46 After a review of authorities dealing with right to support, rights to interfere with groundwater, and implied rights to work and win in grants or reservations of mines and minerals, Parlee J.A. found that:

From these authorities these conclusions follow, that the reservation of the petroleum in the grant of the land enables the appellants to use all reasonable means to extract the petroleum from the earth; that gas in the earth may be likened to subterranean waters and they are subject to like principles of law.

In my opinion, the defendants are entitled to extract all the petroleum from the earth, even if there is interference with and a wastage of the plaintiff's gas, so long as in the operations modern methods are adopted and reasonably used and the provisions of the relevant statute and regulations are observed. ${ }^{47}$

The statute referred to by Parlee J.A. was The Oil and Gas Resources Conservation Act ${ }^{48}$ which provided that an intent and purpose of the Act was "to effect the conservation of the oil and gas resources of the Province and to ... give each owner the opportunity of obtaining his just and equitable share of the production of any pool." ${ }^{49}$ In setting out his decision, Parlee J.A. makes no comment on whether or how Borys is to secure his just and equitable share of production of the gas.

The rule of capture, per se, did not form a part of the Court of Appeal's analysis. What the Court of Appeal did consider was whether the appropriate analogy was to the case law dealing with withdrawal of support from adjacent lands or to the case law dealing with groundwater. If the law of support had been found to be the appropriate analogy, Borys would have had an enforceable right to maintain the gas in place or to compensation to the extent the withdrawal of the gas was found to have resulted in injury; however, the Court of Appeal found that the groundwater analogy was the appropriate analogy and that it applied equally where the competing interests were in split title lands or in adjacent lands. ${ }^{50}$

In upholding the Court of Appeal, the Privy Council also explicitly rejected the submission made by Borys that the proper analogy was to case law dealing with withdrawal of support and resulting subsidence and said that:

The issue is rather as to the right of fortuitous abstraction of gas ... Such a question ... gives rise to no consideration of the right of support but only involves the right of taking from an orifice, bored under express power given in that behalf, fugacious material which makes its way to the surface as a result of natural effluxion. $^{51}$ 
The reference by the Privy Council to the rule of capture formed part of its description of the position and characteristics of the petroleum reservoir under the Borys lands and related to the question of who had the rights to the gas that was produced with the oil. The Court said:

\begin{abstract}
The substances are fugacious and are not stable within the container although they cannot escape from it. If any of the three substances is withdrawn from a portion of the property which does not belong to the appellant but lies within the same container and any oil or gas situated in his property thereby filters from it to the surrounding lands, admittedly he has no remedy. So, also, if any substance is withdrawn from his property, thereby causing any fugacious matter to enter his land, the surrounding owners have no remedy against him. The only safeguard is to be the first to get to work, in which case those who make the recovery become owners of the material which they withdraw from any well which is situated on their property or from which they have authority to draw. ${ }^{52}$
\end{abstract}

As a result, Borys stands for the proposition that in split title cases, the person holding the gas rights may not prevent the holder of the oil rights from producing oil as long as that party's working activities are reasonable and in keeping with industry practice and even if, as a result of natural effluxion, some of the gas cap gas is produced with the oil by the oil rights holder.

Since the Court of Appeal and Privy Council found that Imperial was permitted to "do as they like" 53 with gas that came to the surface with the oil, notwithstanding the fact that it had found that Borys had been granted the rights to the gas, Borys is a rule of capture case by implication. Although Borys claimed damages as an alternative to a permanent injunction, neither court addressed the question of damages. In this sense, Borys implicitly affirmed the rule of capture as a no liability rule in Canadian oil and gas law. In the context of the groundwater analogy, Borys stands for the proposition that the holder of natural gas rights which were not the object of an explicit grant and which have not yet been worked and won does not have a right to have that gas remain in place.

The importance of Borys in Canadian oil and gas law lies in the allocation of entitlements carried out by the courts. In particular, where the Privy Council said "[b]ut the main strength of the respondents' case is that they have a direct grant of petroleum, whereas the appellant has merely such residual rights as remain in him subject to the grant to the respondents," 54 it subordinated the rights of Borys to those of Imperial to find that Imperial was able to exercise its implied right to work and win the petroleum rights granted to it even if the result was a loss of entitlement to Borys. ${ }^{55}$ The fact that at the time of the grant to Borys, Borys would not have considered natural gas to be a valuable commodity (he likely would not have

Ibid. at 67-68 [emphasis added].

Ibid. at 74 .

Ibid. at 77 [emphasis added].

By contrast, in Prism Petroleum Ltd. v. Omega Hydrocarbons Ltd. (1994), 149 A.R. 177 (C.A.), the

Alberta Court of Appeal was dealing with a split title case where the rights of the gas interest owners were explicitly set out in a gas unit agreement. The Court noted that the Borys decision allowed for the possibility that explicitly defined contractual rights, for example, rights expressly dealing with ownership of solution gas, could result in a finding different from that arrived at by the Privy Council. 
had it in consideration at all) seems to have been a factor in the decisions of both the Court of Appeal and the Privy Council.

The next decision that touched on the application of the rule of capture in the Canadian oil and gas context was that of Imperial Oil Limited v. Placid Oil. ${ }^{56}$ Like Borys, Placid Oil did not involve traditional rule of capture facts and the issues did not require the court to decide a capture issue. The issue in that case was the application of s. 3 of The Road Allowances Crown Oil Act, ${ }^{57}$ which provided that: "In every producing oil reservoir one and eighty-eight one-hundredths per cent of the recoverable oil shall be deemed to be within, upon or under road allowances and shall be the property of the Crown." ${ }^{, 58}$

In light of that section, the courts asked whether the respondent, the lessee under a private lease, was obliged to pay royalties on all of the oil produced from the leased lands or only on the oil produced less the 1.88 percent deemed to be the property of the Crown. The successive courts hearing the Placid Oil case all arrived at the same ultimate conclusion that the respondent was not obliged to pay royalties on the 1.88 per cent of oil deemed to be the property of the Crown - however, they arrived at that conclusion by different means. Their comments on the issue of ownership and the rule of capture are noteworthy.

The trial judge found that the effect of s. 3 of the RACOA was that 1.88 percent of the petroleum actually recovered from the leased lands was the property of the Crown. The Court of Appeal, on the other hand, found that s. 3 of the RACOA did not vest title in the Crown of 1.88 percent of all oil in situ in every producing reservoir. The Court of Appeal also said that the section did not alter the rule of capture which, if it applied, would result in ownership of oil produced from the well, even if originating from under a road allowance, vesting in the producer. Finally, in finding that the rule of capture did not apply to vest ownership of the petroleum recovered in the producer, the Court of Appeal held that the effect of $\mathrm{s}$. 3 of the $R A C O A$ was to create the fiction that of all the oil produced from the lands, 1.88 percent was produced from within and upon road allowances at which point ownership of that 1.88 percent was vested in the Crown.

The Supreme Court of Canada also rejected the argument that the effect of s. 3 of the $R A C O A$ was to give the Crown ownership of 1.88 percent of the oil in situ, but based its finding on its interpretation of "producing oil reservoir." 59 The Court found that the consequence of the application of the section was that, of the oil actually produced from the lands regardless of where it originated, 1.88 percent belonged to the Crown and, as a result, the respondent was not required to pay royalties on that oil.

In rejecting the appellant's submission that the rule of capture applied to nullify the effect of s. 3 of the RACOA so that the respondent became the owner of all oil produced from the leased lands, the Court set out the passage from Borys last quoted above and said:

[1963] S.C.R. 333 [Placid Oil].

S.S. 1959, c. 3 [RACOA].

Ibid., s. 3.

Placid Oil, supra note 56 at 337. 
Lord Porter has here summarized the legal position of a landowner from within whose lands oil has migrated to the land of an adjoining landowner by reason of the operation of a well upon that land. Such, in the absence of s. 3 of the Act, would have been the legal position of the Crown in respect of oil which migrated from beneath a road allowance because of the operation of a well on adjoining land.

Section 3, however, declares a property interest in the Crown of 1.88 per cent of all the recoverable oil within the whole of a producing reservoir. This is a property interest, not in relation to oil situated beneath the surface of specific lands, but in respect of a portion of all the oil in the whole of a reservoir. The result is that, no matter to where the oil in that reservoir migrates, the Crown's interest remains in it and, on production, the property interest still remains. ${ }^{60}$

So Placid Oil stands for the proposition that the common law rule of capture may be varied by legislation and, in particular, that appropriately worded legislation may attach property interests to petroleum, no matter where it may be located within a reservoir or where or by whom it may be produced, that remain attached to petroleum when it is produced.

While not an oil and gas case, Canada (National Capital Commission) v. Pugliese, ${ }^{61}$ was a case which dealt with the taking of groundwater from under the land of a neighbour thereby causing injury. The Court of Appeal decision in Pugliese ${ }^{62}$ marked a turning point in the law relating to the appropriation of groundwater in Canada because it recognized, for the first time, that an owner could bring an action in negligence or nuisance for damages caused by subsidence resulting from the withdrawal of groundwater from beneath their lands by an adjacent owner. ${ }^{63}$ In affirming the decision of the Court of Appeal, the Supreme Court of Canada assumed the correctness of the rule of capture as stated in English law and in particular the principle that any damage is damnum sine injuria. The Court then found that s. 37 of The Ontario Water Resources Commission Act ${ }^{64}$ had modified that principle by limiting a landowner's rights to withdraw groundwater with impunity. Specifically, the Court found that in setting the daily limit on groundwater extraction, the legislation established reasonable limits on landowners' property rights and where a landowner extracted groundwater in excess of the limit without a licence to do so, he or she could be found liable in negligence or nuisance for any resulting damage to his or her neighbour's lands. Pugliese affirms that the rule of capture may be modified by legislation and, in particular, that legislation may establish limits on the no liability aspect of the rule.

In Lickacz v. Magna Petroleums $L t d .{ }^{65}$ the court was faced with a dispute among petroleum companies and royalty owners regarding the effect of amendments to applicable conservation legislation. The plaintiff, Mr. Lickacz, and three others each owned one-quarter of one section of land. Each executed oil and gas leases relating to the relevant quarter with

Ibid. at 338 .

[1979] 2 S.C.R. 104 [Pugliese].

(1977), 17 O.R. (2d) 129 (C.A.) [Pugliese Appeal].

In its decision, the Court of Appeal employed modern tort law principles to ameliorate the harshness of the traditional property law approach to the consequences resulting from the abstraction of percolating groundwater. Ibid. at 150-51.

R.S.O. 1970, c. 332. Section 37(3) set a daily production limit on groundwater of 10,000 gallons per day and established penalties for production in excess of that amount without a licence.

(1993), 160 A.R. 193 (Q.B.) [Lickacz]. 
the defendant oil companies. One of the defendant oil companies had drilled a gas well on the quarter owned by the plaintiff. The lease agreement between the plaintiff and the defendant provided for royalties payable to the plaintiff in the amount of 12.5 percent of gas production from wells drilled on his lands. The lease agreement did not contain pooling provisions and, at the time the lease was entered into, the relevant conservation legislation did not provide for pooling orders. The well penetrated a natural gas pool that extended from the plaintiff's quarter section of land under three adjacent quarters so the oil company sought and obtained a pooling order that incorporated the Lickacz quarter with the three adjacent quarters overlying the gas pool. The resulting pooling agreement allocated 35 percent of the total production from the pooled lands to the owner of the well on the Lickacz lands. The defendant oil company determined that, as a result of the pooling, it should calculate royalties as though the gas it produced was produced equally from all four pooled quarters. Lickacz claimed that the rule of capture trumped the pooling agreement so that he was entitled to the benefit of a royalty on all of the production from the well on his lands.

The trial judge accepted that the rule of capture applies to oil and gas in Alberta and in rejecting Lickacz's argument, affirmed that the rule can be modified by legislation. In particular, the trial judge noted that the rules and regulations enacted pursuant to the Alberta Oil and Gas Resources Act in 1952, ${ }^{66}$ specifically stated that the spacing unit and pooling provisions relied on by the oil company defendants, were "clearly was intended to change the old concept of the rule of capture." ${ }^{67}$ In the result, notwithstanding the fact that natural gas originally situated under lands adjoining the Lickacz lands was produced through a single well drilled on the Lickacz lands, the production and associated royalties were to be allocated among all the pooled lands.

What is most interesting about Lickacz, however, is that the trial judge went on to comment on the law that would apply in the event he was wrong about the effect of the pooling provisions of the Act. The judge in Lickacz was clearly troubled by the consequences of the strict application of the rule of capture. He found that the concept of equitable pooling developed by the courts in some U.S. states was a sound and fair approach that could be adopted in Alberta. Equitable pooling would ensure the allocation of production and sharing of royalties among all of the lands that were within the same spacing unit overlying the pool. The effect of this would be to apply an apportionment rule rather than the rule of capture. Alternatively, the trial judge was of the view that the Judicature Act ${ }^{68}$ required the Court to take notice of equitable principles. He then found that the equitable doctrine of unjust enrichment could be used to take into account the fact that some of the gas produced from the well at issue originated from under lands owned by persons other than the plaintiff and that, in keeping with the established practice in the oil and gas industry, such production should be pooled and shared equitably.

Lickacz confirms the application of the rule of capture in Canadian oil and gas law and that it may be modified by conservation legislation; however, Lickacz is notable as an indication of the different approach courts, in Alberta in any event, might take in 
conceptualizing the problem in order to allocate entitlements in a manner that avoids the effects of the strict application of the rule of capture.

The next Canadian oil and gas case to consider the rule of capture was Alberta Energy Co. v. Goodwell Petroleum Corp. Ltd. ${ }^{69}$ Goodwell was an appeal from a decision of the Alberta Energy and Utilities Board (AEUB) (as it then was), made at the application of Goodwell to shut in bitumen wells drilled by Alberta Energy Company (AEC) (as it then was). Goodwell held Crown granted natural gas rights in the same lands on which AEC had drilled the bitumen wells pursuant to its Crown granted bitumen rights. The AEUB had given two primary reasons for shutting in the wells. The first was that conservation required it; the AEUB had determined that significant volumes of initial gas cap gas were being produced with the bitumen and the AEUB was concerned that such production might negatively impact bitumen recovery. The second was that AEC did not have the rights to produce gas cap gas. AEC and Goodwell held their respective rights through express grants in the form of Crown leases. In other words, each had an interest in split title lands from a common lessor: a “classic" split title situation. ${ }^{70}$ AEC's rights to bitumen had been granted subsequent to Goodwell's rights to the petroleum and natural gas. Goodwell had not taken any steps to exercise its rights to produce gas from the split title lands. ${ }^{71}$

After the AEUB admitted that AEC had taken adequate conservation measures, ${ }^{72}$ the Court found that there was no conservation basis for the shut in order. With respect to whether AEC had the necessary legal right to produce gas-cap gas incidentally with the bitumen it actively sought, the Court referred to Borys and noted that at the time of that decision, "the corollary right to produce initial gas-cap gas incidental to petroleum recovery was confirmed."73

The AEUB argued before the Court that the Borys principles were distinguishable from a case involving an oil sands lease on one or more of three bases. First, the science of bitumen extraction was sufficiently different from conventional oil and gas production that the facts weren't comparable. Second, the terms of the oil sands leases themselves overrode Borys and third, the statutory regime applicable to oil sands abrogates the Borys principles. The Court rejected all three bases for distinguishing Borys.

The Court noted that longstanding common law principles (that is, the rule of capture) need to be considered in the current context, including the specific terms of the rights granting instruments involved and the presumed intentions of the parties. ${ }^{74}$ The Court set out detailed reasons in support of its finding that the oil sands lease contained implied terms giving AEC the right to take gas-cap gas that was produced as a natural result of its operations to recover the oil. The Court of Appeal extended Borys in finding that when two parties have sought, paid for, and received the right to work and recover different

2003 ABCA 277, 339 A.R. 201 [Goodwell].

Don M. Tedesco, “Gas Over Bitumen — Bitumen Over Gas!” (Paper presented at 2004 Canadian Bar Association Mid-Winter Meeting) at 2.

Goodwell, supra note 69 at para. 7.

Ibid. at para. 16.

Ibid. at para. 5.

Ibid. at para. 81. 
hydrocarbons from the same lands, they do not need the agreement of the other party prior to exercising their rights. ${ }^{75}$ The judgment in Goodwell is noteworthy in this respect, because by contrast to Borys, both parties held specific grants of rights to petroleum and, at the time of the grant, Goodwell, unlike Borys, most certainly would have had an expectation of profiting from the exercise of its rights to the natural gas.

The judgment in Goodwell is also noteworthy because of the Court's focus on interpreting the terms of the two overlapping leases ${ }^{76}$ so as to avoid diminishing the value of either lessee's interest. ${ }^{77} \mathrm{~A}$ consistent theme running throughout the Court of Appeal's judgment is that of avoiding an outcome that would defeat either party's reasonable expectations in the circumstances. Repeated references to Goodwell's right to compensation ${ }^{78}$ indicate that the Court was relying on a right to compensation to address Goodwell's expectations. Such reliance is not consistent with the early, strict application of the rule of capture where, absent other legal bases for compensation, the courts recognized no actionable loss or damage arising from the capture.

Finally, the Supreme Court of Canada had another opportunity to comment on the rule of capture in Anderson v. Amoco Canada Oil and Gas. ${ }^{79}$ In Anderson, the issue as stated by the Supreme Court of Canada was the ownership of hydrocarbons produced from a single well drilled on split title lands. The dispute was between "petroleum" owners and "nonpetroleum" owners as to who had the rights to the various substances in the reservoir and to what extent those rights changed, if at all, as those substances underwent phase change ${ }^{80}$ in the course of production from the reservoir. The respondents had not taken any steps to explore for or recover their gas. Once again, while the rule of capture was a focus of argument in the case, the facts did not raise a traditional rule of capture issue involving neighbouring properties.

In Anderson, one argument presented to the Court was that the rule of capture should be extended and modified so that gas in solution in the reservoir, which belonged to the petroleum owner, became the property of the natural gas owner when it changed phase and evolved to natural gas in the wellbore, which was owned by the petroleum owner. ${ }^{81}$ This would have amounted to an extension or alteration of the rule of capture because under the

Ibid. at para. 80. In Borys, only one party had actively sought rights to hydrocarbons. The other had received a grant of land from which petroleum rights had been reserved, leaving a remainder interest in natural gas.

76

77

78

That is, the oil sands lease and Goodwell's conventional petroleum lease.

Goodwell, supra note 69 at para. 82.

Indeed, the parties were involved in separate litigation over an alleged production sharing agreement and the appropriate approach to calculating compensation to be paid to Goodwell. See Goodwell Petroleum Corp. Ltd. v. Alberta Energy Co. Ltd., 2003 ABQB 852, [2003] A.J. No. 1301 (QL).

2004 SCC 49, [2004] 3 S.C.R. 3 [Anderson].

For example, from solution gas to natural gas.

Anderson, supra note 79 at para. 38; James M. Pasieka \& N. Glenn Cameron, “Ownership of Evolved Gas in Split Title Situations" (1991) 29 Alta. L. Rev. 19. In this article, the authors argue that the rule of capture does not deal with ownership conflicts in the same parcel of land and should not apply since the rule "recognizes the impossibility of determining whether any production from a reservoir is from the well owner's property or an adjoining property.... It is, however, possible to distinguish between liquids and gases and to measure the extent to which natural gas in excess of natural gas in solution with petroleum is produced" (at 26). 
rule, it is the person who has taken the risk and gone to the expense of drilling the well who benefits from the application of the rule of capture. In commenting on the rule of capture the Court said:

\begin{abstract}
The rule of capture developed as a rule of non-liability between owners of separate tracts of land. Since underground pools often extend beyond a single tract of land, it prevents A from having a valid claim against B when B captures from under his land a substance that was originally under A's land. In Borys, Lord Porter found this rule would apply to oil and gas and A's only remedy was to drill its own well and begin production. The unhindered application of this rule would lead to a race to produce, and because this uncontrolled development actually reduces overall hydrocarbon recovery, that rule has been subsumed by the regulatory environmental reserve and preservation provisions of legislation such as the Oil and Gas Conservation Act, R.S.A. 2000, c. O-6. ${ }^{82}$
\end{abstract}

The Court declined to apply the rule of capture in the manner advocated by the appellants saying that the rule could not be applied to alter the division of interests in petroleum and non-petroleum substances that the parties had originally agreed to. Anderson tells us that in Canada, absent agreement between the parties or legislative provisions to the contrary, the rule of capture does not operate across hydrocarbon phase changes.

In summary, the cases discussed above may be divided along two lines, the split title cases of Borys, Goodwell, and Anderson and the cases of Placid Oil, Pugliese, and Lickacz, wherein the traditional rule of capture was an issue.

In the split title cases, the parties are not in competition for the same resource. Indeed, each hold independently granted rights to different substances that may or may not be found in the same lands. To the extent that one party is not able to exercise its rights without affecting the rights of the other, their rights may be said to be competing.

In the split title cases, the courts interpret the instruments granting the rights to determine the rights of the parties relative to one another. In those cases, the rule of capture has been applied, at least by implication, to address the fact that the party who was first to take the risk and invest the capital to exercise its rights unavoidably captures some of the other party's resource. Whether the result is that the first party "owns" the captured resource or is simply not liable for its capture has not been decided. If the result is the former, then the capturing party can deal with the resource as it sees fit with no recourse by the other party. If the result is the latter, the capturing party may hold the resource as trustee for the other party and be held liable to account. However, to date, the consequence for the complaining party has been the same in either case: absent legislative, contractual, or licence based provisions to the contrary, that party's loss will go without redress.

The split title cases are similar to the traditional rule of capture cases because they establish that a party who does not, or perhaps cannot, due to conservation concerns, exercise 
his rights in a timely manner may see those rights diminished or eroded when the competing rights holder exercises her rights. ${ }^{83}$

Finally, the split title cases also establish that the rule of capture may not alter previously established contractual rights to substances that may be found together in the same lands.

While Canadian courts have not had to specifically address the applicability of the rule of capture to a set of traditional facts in the oil and gas context, the consistency of comments on the matter at all levels of court clearly indicate that the rule of capture would be applied in the ordinary case of a dispute over rights to petroleum that may have migrated from B's lands to be produced through A's well located on A's adjacent lands as long as A's drilling and production activities fell within the usual industry practice. In the result, A would not be liable to B for production of the migrated petroleum and would be the owner of such petroleum as may have migrated from under B's lands.

In addition, the more traditional line of cases discussed above clearly establishes that the rule of capture may be modified or completely displaced by legislation. More specifically, the more traditional line of cases clearly establishes the following: first, legislation may limit a landowner's rights to withdraw unlimited quantities of a fugacious substance from under his or her lands and in the event limits have been established and a landowner exceeds those limits without a licence or other authority to do so, then he may be liable in negligence or nuisance if his action results in damage to his neighbour; second, conservation provisions in legislation may modify or override the rule of capture; and third, appropriately worded legislation may establish ownership in oil or gas regardless of the origin within a pool of that oil or gas. The fact that legislation may alter or curb the rule of capture is essential to the functioning of oil and gas conservation legislation.

\section{B. LEgISLATION}

In Canada, legislation containing conservation measures that include provisions that have the effect, whether direct or indirect, of modifying the traditional rule of capture, was introduced early in the development of the oil and gas industry. ${ }^{84}$ The Canadian and in

Where the split title case is a gas over petroleum or bitumen situation, the question becomes the following: can the gas rights holder really protect itself from capture by being the first to produce? In Alberta, the answer is likely not, since the regulator has established a policy of maintaining the gas cap on an oil or bitumen reservoir to facilitate primary production of the underlying substances. Having said that, those with gas rights may apply to the Board for approval to produce the gas either alone or in conjunction with the oil or bitumen. See Alberta Oil and Gas Conservation Act, R.S.A. 2000, c. O-6, s. 39(1)(f) [Alberta Conservation Act]; AEUB, Directive 065: Resources Applications for Conventional Oil and Gas Reservoirs (3 July 2007), online AEUB <http://www.ercb.ca/docs/documents/directives/ Directive065.pdf> [AEUB Directive 065].

84 For example: the first regulations protecting the rights of adjacent land owners/occupiers were introduced pursuant to the Oil and Gas Wells Act, R.S.A. 1942, c. 67 through provisions establishing minimum well distances from tract boundaries. G.W. Govier in "The Administration of the Oil and Gas Conservation Act in Alberta" (1969) 7 Alta. L. Rev. 341 at 341:

The present concepts of conservation have been developed over the past 35 years. They originated in Texas and Oklahoma following the discovery of substantial oil fields and the resultant overproduction, waste and collapse of prices. Initially regulations were instituted to protect correlative rights and eliminate surface waste.... The development of oil and gas conservation in 
particular, the Alberta approach, was directly informed by the American experience. ${ }^{85}$ In turn, Alberta's conservation legislation paved the way and is said to have set the standard for Canada's other oil and gas producing provinces. ${ }^{86}$ Such legislation has since been introduced in every jurisdiction in Canada with petroleum production. ${ }^{87}$

The introduction of conservation legislation early in the development of the Canadian oil and gas industry is widely viewed as being a necessary response to the unfettered application of the rule of capture and the economic and physical waste resulting from the consequent race to drill and produce. ${ }^{88}$ At the time however, it was not immediately embraced by industry $^{89}$ with some, perhaps many, resolutely insisting on the application of the rule of capture and their right to compete for production. ${ }^{90}$ This, notwithstanding the fact that the incentive to drill created by the rule of capture was resulting in a glut of oil production and a consequent drop in oil prices. ${ }^{91}$

The introduction of the concept of correlative rights ${ }^{92}$ in conservation legislation limits the effects of the rule of capture. All oil and gas conservation legislation in Canada (hereafter referred to as conservation legislation), except that at the federal level and in Ontario, includes a reference to either protection of correlative rights or to the opportunity to secure a share of oil or gas from a pool as a purpose of the legislation. For example, the Saskatchewan Oil and Gas Conservation Act provides: "The purposes of this Act are ... to allow each owner the opportunity of obtaining that owner's share of the oil or gas from a pool."93 The wording of the purposes provision of the Alberta Oil and Gas Conservation $A c t^{94}$ and the Yukon Oil and Gas $A c t^{95}$ are very similar. By contrast, the British Columbia

Alberta somewhat parallels that in the United States although we probably always have had more emphasis on the elimination of waste and the desirability of maximum recovery. Breen, supra note 8 at liii.

Ibid. at 503.

See Alberta Conservation Act, supra note 83; Oil and Gas Act, R.S.Y. 2002, c. 162 [Yukon Oil and Gas Act]; Petroleum and Natural Gas Act, R.S.B.C. 1996, c. 361 [B.C. Petroleum and Natural Gas Act]; Oil and Gas Conservation Act, R.S.S. 1978, c. O-2 [Saskatchewan Conservation Act]; Canada Oil and Gas Operations Act, R.S.C. 1985, c. O-7 [COGOA]; Oil and Gas Act, S.M. 1993, c. 4, C.C.S.M. c. 034 [Manitoba Oil and Gas Act]; Gas and Salt Resources Act, R.S.O. 1990, c. P.12 [Ontario Resources Act]. See Neufeld \& Grant, supra note 9; Rowland Harrison, "Regulation of Well Spacing in Oil and Gas Production” (1970) 8 Alta. L. Rev. 357; Paseika \& Cameron, supra note 81; Cawley, supra note 9. Breen, supra note 8 at 61-62, 103.

Ibid. at 92.

Ibid. at 103 .

In s. 1(1) of the Ontario Resources Act, supra note 87, “correlative rights” are defined to mean: "the right of every owner of a property in a pool of oil or gas to produce from that property the owner's proportionate share of the oil or gas, or both, in the pool.” In s. 1(1) of the Manitoba Oil and Gas Act, supra note 87, "correlative rights" are defined to mean: "the rights of an owner to receive the owner's share of oil and gas produced from a pool." Note that what amounts to a "share" is not defined. The difference in the wording of the two definitions is interesting, specifically, the use of "receive" in the Manitoba statute. The definition of correlative rights in the Ontario statute clearly limits the application of the rule of capture because it assures to direct competitors for the same resource a right to produce that resource. The definition of correlative rights in the Manitoba statute suggests a more severe limit on the rule of capture in that a person's correlative rights are satisfied only if they actually receive some of the oil and/or gas produced - regardless of whether they exercised their opportunity to produce. Saskatchewan Conservation Act, supra note 87, s. 3 (1)(c).

Alberta Conversation Act, supra note 83, s. 4(d).

Yukon Oil and Gas Act, supra note 87, s. 2(f). 
Oil and Gas Commission Act provides: "The purposes of the commission are to ... [assist] owners of oil and gas resources to participate equitably in the production of shared pools of oil and gas"96 and the Manitoba Oil and Gas Act provides: "The objects and purposes of this Act are ... to protect the correlative rights of owners." 97

In light of the definition of "correlative rights" in the Manitoba Oil and Gas Act, ${ }^{98}$ it is arguable that the Manitoba conservation legislation, with its emphasis on participation in production and on receiving a share of production, provides a foundation for more direct and extensive limits on the rule of capture than that provided by the more passive language emphasizing opportunity to produce that is employed in the Saskatchewan, Yukon, and Alberta conservation legislation. Of course, to the extent correlative rights are mentioned only in the purposes provisions of particular conservation legislation, they become only one of a number of factors that those administering the legislation may take into account in arriving at decisions under specific legislative provisions.

The earliest conservation provisions were well spacing requirements, drilling target areas, and minimum set-backs. All conservation legislation contains such provisions. The requirement of specified well spacing, along with control of production, forms the core of conservation legislation. ${ }^{99}$ By limiting the number of wells that may be drilled within a given geographic area, well spacing regulations may have the effect of protecting property rights and mitigating the rule of capture ${ }^{100}$ by creating a buffer zone around a well. Where there are multiple holders of oil and gas rights within a spacing area, the effectiveness of spacing and target provisions in eliminating or minimizing capture depends on individual reservoir characteristics and the actual drainage areas of given wells.

Administrators of conservation legislation may adjust well spacing, target area, and setback requirements to take into account the phase of development of a given region and policies to maximize total recovery of petroleum over the lifetime of reservoirs. For example, in 2005, the AEUB introduced proposed changes to well spacing that would increase the permitted density. In its Bulletin announcing the proposed changes the AEUB said:

Well spacing establishes the number of subsurface drainage locations necessary to maximize the recovery of oil and gas in a reservoir. Well spacing provides equity protection for competitive mineral right owners and maximizes the conservation of the resource.

Existing regulations establishing baseline well densities were created for the early development stage of the Alberta sedimentary basin, in which a few companies developed large oil and gas reservoirs. Today, a larger number of companies are developing smaller and lower productivity reservoirs, and higher well densities are

S.B.C. 1998 , c. 39, s. 3(a)(iv).

Manitoba Oil and Gas Act, supra note 87, s. 2(1)(c).

Ibid., s. 1(1).

Breen, supra note 8 at xlvi. The first regulatory order of Alberta's newly formed Petroleum, Natural Gas Conservation Board in 1938 decreed that the number of wells to be operated in the Turner Valley Field would be restricted to one well for every 40 acres and without Board authorization, no well was to be closer than 660 feet from an adjoining boundary.

Harrison, supra note 88 at 363. 
frequently required to optimize recovery of the oil and gas. As a result, there has been a significant increase in the number of applications requesting higher well density spacing. ${ }^{101}$

While conservation provisions providing protection from capture may provide needed assurance to parties engaged in exploration in the early years of development of a basin or region, they may require refinement as a basin matures and targets become smaller and more technical (for example, a move from the large pinnacle reef plays such as Leduc to more localized stratigraphic plays such as the Gilby Glauconite) with less risk of capture because of the limited size and more complicated nature of the reservoirs.

Minimum setbacks that are measured from boundaries ${ }^{102}$ between adjacent landowners or rights holders provide some protection from capture. Regulators may also require applicants for exemption from spacing unit requirements to propose adequate buffer zones between the proposed well and the boundary of the applicant's holding or of the unit area. ${ }^{103}$ Saskatchewan, which produces a significant amount of heavy oil that is often produced using horizontal well technology, has specifically provided for minimum setbacks from the producing zone of a horizontal well to limit the scope for capture from adjacent lands. ${ }^{104}$

Well spacing, target areas, and set-back requirements establish buffer zones around and between wells and in that way may reduce the scope for capture by any given well; however, to the extent that arbitrarily established spacing units do not fit or encompass the underlying pool, they cannot eliminate capture but they do preserve equity.

Similarly, there are other provisions in conservation legislation that may be used to limit the potential for a well drilled by A to produce petroleum from under lands held by B and thus limit the rule of capture. Those provisions include powers given to the regulator to make production orders and rateable take orders. Allowable production orders typically include the power to designate an area of surface and subsurface lands that is to be allocated to a well for the purpose of fixing allowable production. ${ }^{105}$ Allowable production provisions can be used to limit, in theory at least, the effective reach of a well (described as drainage area) and the possibility that it will produce oil or gas from under adjoining lands. How effective such orders are at preventing or limiting capture depends on the characteristics of the individual

101 AEUB Bulletin 2005-08, Consultation Regarding Proposed Changes to Reservoir-Related Well Spacing Regulations, Application Requirements, and Application Review Process (10 March 2005), EUB Bulletin 2005-08, online: ERCB <http://www.ercb.ca/docs/documents/bulletins/Bulletin-2005-08.pdf> at 1.

102 For example: s. 30.3 of the Saskatchewan Oil and Gas Conservation Regulations, R.R.S. c. O-2, Reg. 1 [Saskatchewan OGCR], provides that: "Unless otherwise ordered by the minister ... (a) for heavy oil areas the productive horizontal section of a horizontal well must be set back: (i) a minimum of 100 metres from a diversely owned lease boundary." 87, s. 17(1)(d). The federal Canadian Petroleum Resources Act, R.S.C. 1985 (2nd Supp.), c. 36 and COGOA, supra note 87, regime does not contain such provisions. 
reservoir, how well tailored the order is to the particular reservoir, and whether correlative rights or drainage are specific factors to be addressed by such orders. ${ }^{106}$

Rateable take orders for gas allow the regulator to allocate or apportion production among gas wells in a pool. ${ }^{107}$ When rateable take provisions were first introduced in Alberta, they did not explicitly allow the Board to apportion production in order to allocate it fairly among producers, but the Board held that it did have that discretion. ${ }^{108}$ The legislation was later amended in a manner that reflected the Board's practice. ${ }^{109}$ The Yukon Oil and Gas Act contains a similarly worded provision and gives the Minister broad powers to limit production from, and/or allocate production to, wells. ${ }^{110}$

Common carrier, common purchaser, and common processor orders allow a regulator to alleviate constraints facing a party who would otherwise be producing oil or gas but who can not because they do not have, and have not been able to negotiate, access to a pipeline, to market or to processing facilities. ${ }^{111}$ Common carrier, purchaser, and processor orders indirectly limit the rule of capture because, for example, a party who does not have access to a pipeline may experience drainage while other parties with wells producing from the same reservoir are producing and transporting the commodity on the local pipeline system. If the party experiencing drainage obtains a common carrier order, it can then begin producing and secure a share of production from the reservoir.

The incorporation of common carrier, purchaser, and processor provisions in conservation legislation has been described as being "an incorporation of the doctrine of correlative rights" 112 into the management and regulation of oil and gas production. They provide a means for ensuring that an owner of oil or gas rights is not prevented, through circumstances

British Columbia's daily oil and gas allowable provisions (ss. 73 and 88 of the B.C. Petroleum and Natural Gas Act, supra note 87) specifically give the Oil and Gas Commission the ability to limit production from wells within a unit area if it believes that production is adversely affecting production from a well outside the unit area. Similarly, the Commission announced in Bulletin E-89-09 that gas allowables would be eliminated for the majority of gas wells in British Columbia as of 1 January 1990 except where a well was completed off-target and correlative rights were an issue, online: Government of British Columbia <http://www.ogc.gov.bc.ca/documents/informationletters/emd-il/e89-09.htm>. Provisions in Alberta's conservation legislation give the Board the power to make prorationing orders in respect of oil production, s. 34 of the Alberta Conservation Act, supra note 83. While those provisions can limit capture by allocating production among wells, the provisions were intended to address market conditions and have not been used for some time. Neufeld \& Grant, supra note 9 at 143.

109 Section 36 of the Alberta Conservation Act, supra note 83 [emphasis added], now says:

(1) The Board may, by order, restrict

(a) the amount of gas, or

(b) where gas is produced in association with oil, the amount of gas and oil, that may be produced during a period defined in the order from a pool in Alberta.

(2) The restriction referred to in subsection (1) may be imposed by either or both of the following means:

(b) by distributing the amount of gas that may be produced from the pool or part of the pool in an equitable manner among the wells or groups of wells in the pool for the purpose of giving each well owner the opportunity of receiving the well owner's share of gas in the pool." Yukon Oil and Gas Act, supra note 87, ss. 17(1)(d).

See ibid., ss. 74-76; Alberta Conservation Act, supra note 83, ss. 48-56.

Hebb, supra note 9 at 442 . 
beyond its control, from exercising its opportunity to obtain its share of production from a pool. Of course, such orders do not eliminate capture because the party seeking the order will suffer drainage until he actually obtains the required access to a carrier, processor, or purchaser. Indeed, for the most part, demonstrating drainage is a necessary prerequisite to obtaining one of the common service orders. ${ }^{113}$

Pooling refers to the combination, through agreement, of working interests for different, contiguous tracts within the area of a drilling spacing unit where a drilling spacing unit is the minimum area established by the relevant regulatory authority for the purpose of drilling a well. ${ }^{114}$ All producing jurisdictions in Canada effectively require pooling in order to license a well where there is more than one tract in a spacing unit. Pooling may be voluntary ${ }^{115}$ or compelled by order. ${ }^{116}$ Compulsory pooling orders provide a means for the owner of a partial interest in a tract to avoid drainage by competitors with other wells in adjoining lands; ${ }^{117}$ however, in this case, as with the common carrier, purchaser, and processor scenario, if the competition is actually producing from offsetting wells, then the applicant for a pooling order will experience drainage unless and until the effective date of the order.

Unitization "is the joint, coordinated operation of an oil or gas reservoir by all the owners of rights in the separate tracts overlying the reservoir or reservoirs."118 Unitization was identified early on as being the most, and by some accounts only, effective way of eliminating the evils of the rule of capture. ${ }^{119}$ As with pooling, unitization may also be voluntary ${ }^{120}$ or compulsory. ${ }^{121}$ Because unitization agreements are entered into after an oil or gas discovery has been made and, at least in North America, often after the primary production phase of a pool, they cannot prevent all drainage.

Both pooling and unitization provide a means by which parties with unequal ${ }^{122}$ opportunities to obtain production from a pool can avoid the effects of the rule of capture. While the potential for capture is eliminated within a pooled or unitized area, it is possible that drainage to a pool or unit or from a pool or unit could occur. In addition, if no provision is made in conservation legislation for compulsory unitization, then its usefulness is limited to the goodwill of competitors and the persuasiveness of regulators with a mere mandate to “encourage” unit formation. ${ }^{123}$

Neufeld \& Grant, supra note 9 at 142.

Bankes, supra note 39 at 494.

See B.C.Petroleum and Natural Gas Act, supra note 87, s. 68; Canada Oil and Gas Operations Act, supra note 87 , s. 30.

See B.C.Petroleum and Natural Gas Act, ibid. s. 69; Canada Oil and Gas Operations Act, ibid. s. 31. Neufeld \& Grant, supra note 9 at 146.

Weaver \& Asmus, supra note 35 at 11.

Ibid. at 12-13; Breen, supra note 8 at xl, 184-85.

See Alberta Conservation Act, supra note 83, s. 79(1) and the Yukon Oil and Gas Act, supra note 87, s. 86.

See Manitoba Oil and Gas Act, supra note 87, s. 135(1)(b) which provides: “the minister may make a unit order where the minister is satisfied that, in respect of the proposed unit area, a unit operation ... is necessary or advisable to prevent waste or to protect correlative rights.”

Or even no opportunity without an exemption from spacing requirements or due to other surface access constraints. A party with unequal opportunity may be one who holds rights that fall in a spacing area but outside the target area for drilling a well into a pool.

See Alberta Conservation Act, supra note 83, s. 79(1). 
To date, no jurisdiction in Canada has adopted mandatory unitization whereby all pools must be developed as a unit before production. Alberta is the only producing jurisdiction in Canada that has not made provision for compulsory unitization ${ }^{124}$ whereby the regulator has the discretion to order, on his own motion or in answer to an application, that a pool be developed as a unit.

To summarize, while the specifics of conservation legislation vary across petroleum producing jurisdictions in Canada, all such legislation establishes a variety of means by which the potential for capture may be limited.

On balance, conservation legislation creates more or less equal opportunities for holders of oil and gas rights to produce from a common source of supply, although it does not ensure that each competing rights holder will in fact produce a given, or indeed, any amount of oil or gas. Absent mandatory joint development, the application of the principles set out in current conservation legislation also has the effect of rewarding the first successful risk taker in a new area of exploration. ${ }^{125}$

\section{VieWS OF THE REgUlatoR}

Conservation legislation in Canada is variously administered by boards or other quasijudicial bodies, Ministers, or a combination of government and independent decision making bodies. Publicly available reasons for decisions demonstrate that, in Ontario, Alberta, and British Columbia in any event, the rule of capture is a well accepted part of oil and gas regulatory law in Canada.

In Ontario, where oil was first produced in Canada and where, by contrast with British Columbia, Alberta, Saskatchewan, and the Territories, there is significant private ownership of oil and gas, the rule of capture is considered to be very much a part of the regulatory framework. ${ }^{126}$ The Ontario Mining and Lands Commissioner, who has the responsibility for administering Ontario's conservation legislation, describes the rule of capture as being:

Although the Alberta government was urged to include provisions of compulsory unitization in its early conservation legislation and such provisions were drafted and passed, they have never been brought into force but remain part of the Oil and Gas Conservation Amendment Act, R.S.A. 2000 (Supp.), c. 24. It was thought that leaving the power to make unitization orders hanging over industry's head would encourage voluntary unitization (Breen, supra note 8 at 501-502).

Eugene Kuntz, A Treatise on the Law of Oil and Gas, vol. 1 (Cincinnati: Anderson, 1987) at 113. Kuntz said in support of the rule of capture:

[T]here might be very good reasons for permitting someone else to retain an extracted substance which originally underlay another's land. The production of oil or gas is accomplished only after substantial financial risk and effort have been undertaken. The person undertaking such an enterprise should be extended protection to insure the enjoyment of the natural fruits of such enterprise so long as some firmly established property concept is not offended.... The policy of the law is to favor the diligent.

126 See e.g. Lagasco Inc. v. All Leased Landowners, Unleased Landowners and Lease Interest Holders in the Zone " $B$ " Pool (23 July 2003), The Mining and Lands Commissioner File No. OG 008-02, online: Ontario Ministry of Natural Resources <http://www.mnr.gov.on.ca/MNR_E002172.pdf>. 
whereby those substances found and taken into possession by the operator are within their ownership. While the surface rights are rightfully the landowners no ownership of the oil and gas laying under the lands exists until an operator has taken them into its possession. Ownership is clearly with the working operator. ${ }^{127}$

The rule of capture is balanced in Ontario by the protection of landowners' correlative rights. ${ }^{128}$ In Ontario, the Commissioner takes the view that correlative rights are provided for through spacing unit designations, set-back requirements, and compensation methods. ${ }^{129}$ Ontario's conservation legislation is administered with an emphasis on encouraging oil and gas exploration and production to the benefit of operators, employees, royalty interests and the economy overall. ${ }^{130}$

Alberta's conservation legislation is, and always has been, administered by an independent, quasi-judicial body established for that purpose. Decisions of the Alberta Energy Resources Conservation Board (ERCB) clearly indicate that the Board views the rule of capture as a fundamental part of the oil and gas business in Alberta. For example, the ERCB has said:

The Board acknowledges that the rule of capture is a fundamental principle of common law and entitles the owner of valid oil or gas rights to any oil or gas that it produces through its well, regardless of whether the oil and gas produced originally underlay property owned by the producer. However, the rateable take provisions within the Act authorize the Board to modify the rule of capture and override the competitive operations that are the normal practice in Alberta. The Board considers that a rateable take order would constitute a serious intervention in normal operations and any application for such an order must be given very careful consideration. $^{131}$

\section{By contrast, in dealing with an off-target penalty application, the ERCB has said:}

The Board believes that off-target penalties are meant to mitigate lease line drainage.... [W]here such a penalty appears in any given circumstance to be ineffective and not to serve the intended purpose of protecting correlative rights, a licensee should understand that the party whose reserves are being drained has the option of applying to the EUB for a special off-target penalty or other remedies that address impacts on its correlative rights. ${ }^{132}$

Ibid. at 32 .

Ibid.

Farmers Oil and Gas Inc. v. Robinson (11 March 2005), The Mining and Lands Commissioner File No. OG 003-03, online: Ontario Ministry of Natural Resource <http://www.mnr.gov.on.ca/ MNR E002172.pdf $>$ at 16 .

$130 \quad$ Ibid. at 13.

131 AEUB Decision, 2003-16, supra note 41 at 9-10. In addition, in AEUB Directive 065, supra note 83 at $1-1$, the Board notes that it considers the issuance of a rateable take order to be a "very significant action because it has the potential to override contractual arrangements put in place through normal business practices.”

132 Vermilion Resources Ltd., Clear Energy Inc., Tusk Energy Inc. Rateable Take Special Off-Target Penalty Shane Kiskatinaw D Pool (12 August 2003), AEUB Decision 2003-046, online: ERCB <http://www.ercb.ca/docs/documents/decisions/2003/2003-046.pdf> at 7. 
The ERCB then found that the characteristics of the pool (and hence drainage) were such that a rateable take order represented a better solution to the equity issues raised than an off-target penalty. ${ }^{133}$

The ERCB requires applicants for rateable take orders to demonstrate that their reserves are being drained subsequent to completion of a well on their property and to show whether they have had reasonable opportunities to maximize production through existing wells or new wells ${ }^{134}$ as part of an application for an order. In Alberta, drainage that occurs during a period while parties are negotiating access to facilities is not considered inequitable. ${ }^{135}$

The ERCB focuses on self-help. Its reluctance to modify or interfere with the rule of capture is consistent with a policy of encouraging competition and rewarding risk taking and investment in exploration and development. Having said that, as noted above, in some circumstances the ERCB will take steps to compensate for or limit capture to address inequity between parties.

In British Columbia, responsibility for administering conservation legislation has been divided between the Minister, the Oil and Gas Commission, and the British Columbia Utilities Commission (BCUC). Responsibility for administering various aspects of conservation legislation in British Columbia has been shifted from one entity to another over the years. As a result, the body of published decisions in British Columbia dealing with conservation legislation is not comprehensive and contains gaps in time; however, BCUC decisions from the early $1980 \mathrm{~s}^{136}$ and a decision issued in the last year provide some insight into the regulatory treatment of the rule of capture in British Columbia.

In the early to mid-1980s, the BCUC heard a number of common purchaser applications. ${ }^{137}$ The reasons for decision in those applications made it clear that the BCUC required the applicant to prove that drainage was occurring from a completed well as a prerequisite to a common purchaser order. ${ }^{138}$ They also made it clear that that the rule of capture was an accepted part of competitive petroleum industry practice in British Columbia. $^{139}$

More recently, the BCUC has had occasion to issue reasons for decision in an application for a common carrier/processor order. In that decision, the BCUC adopted some of the

Ibid. at 13.

Ibid.

Enron Oil Canada Ltd. Common Carrier, Common Processor, Allocation of Production Wapiti Area Examiners Report No. 97-6, online: ERCB <http://www.ercb.ca/docs/documents/examiner-reports/ 1997/E97-06.pdf > at 9.

During that period of time, it had the jurisdiction to make common purchaser orders naming the British Columbia Petroleum Corporation as the common purchaser.

See e.g. In the Matter of the Utilities Commission Act and In the Matter of an Application by the British Columbia Petroleum Corporation, 26 September 1980; In the Matter of the Utilities Commission Act, SBC 1980, c.60, as amended and In the Matter of an Application by Rupertsland Resources Co. Ltd., 28 October 1982; In the Matter of the Utilities Commission Act S.B.C. 1980, c.60, as amended and In the Matter of an Application by Wainoco Oil and Gas Limited, 8 October 1985 [Wainoco].

See e.g. Wainoco, ibid. at 5-6.

Supra note 137. 
criteria used by the Alberta Energy Resources Conservation Board when considering applications for common orders. ${ }^{140}$ The BCUC also determined that it will consider competitive drainage as a factor to be taken into account in an application for a common order. $^{141}$

Like the Board, the BCUC considers competitive drainage to be part of the usual course of the industry, and if it is not "inequitable," then it is acceptable. ${ }^{142}$ Based on the decisions issued by the BCUC to date, we know that drainage in British Columbia is not inequitable if the party experiencing drainage did not pursue all of its options for securing access to transportation and processing. ${ }^{143}$ In addition, the BCUC has adopted the view that drainage by a party who was the first to begin production from a pool and who has taken some notable risk to bring it into production is not inequitable. ${ }^{144}$

It seems that the conservation provisions administered by the BCUC will be administered in line with the Alberta and Ontario approaches encouraging development of oil and gas while relying on the rule of capture as an incentive mechanism.

\section{Current State of The Rule of Capture in Canada}

What conclusions can we draw from the foregoing about the current state of the rule of capture in oil and gas law in Canada? While the traditional rule of capture case has not been litigated in Canada, the consistency of judicial and quasi-judicial commentary leads to the presumption that it would apply. Indeed, regulators have explicitly adopted the traditional rule of capture as an integral part of the overall conservation regimes they administer.

Two distinct lines of reasoning emerge from what are described as rule of capture cases in oil and gas common law in Canada: (1) the subordinate rights approach on split title lands; and (2) the more traditional approach for adjacent lands. In both cases, the courts rely on their interpretation of rights granting instruments and of the parties' reasonable expectations, along with such legislative guidance as may be available, to assess parties' rights and allocate entitlements in cases where the rule of capture has been raised.

The reasoning of the courts in both lines of cases leads to the conclusion that the rule of capture in oil and gas law in Canada is a sui generis rule. It is not applied as a rule of property law rather it is applied in support of the subordination of the property rights and interests of one party to those of another. Nor is it applied strictly as a no liability rule although it has not been specifically argued in that context — rather it is applied in support of contract-based reasoning to complete the allocation of entitlements between parties. 
Finally, the rule of capture has not been rationalized as a rule of equity although the later cases of Lickacz and Goodwell indicate that equitable considerations may come into play.

At the end of the day, when the rule of capture is invoked, it is to justify the finding that when a person incidentally produces a hydrocarbon to which another person holds rights that have not yet been exercised, then absent contractual or legislative provisions to the contrary, the first person may retain those hydrocarbons with no recourse by the other party.

While all conservation legislation contains provisions that can limit capture, some conservation legislation explicitly encourages a proactive approach to balancing correlative rights. Publicly available information indicates that, in general, conservation legislation is administered with an emphasis on self-help and on the premise that capture of oil and gas from adjacent lands is not undesirable per se, as it is a natural consequence of a competitive industry.

Finally, the case law and the regulatory decisions that have addressed the rule of capture lead to the conclusion that the rule of capture is a means of justifying an allocation of rights and entitlements between parties that rewards initiative, risk, diligence, and capital investment.

The following more specific conclusions may also be drawn about the current state of the rule of capture in Canada:

- The rule of capture may be modified by legislation. One example being legislation that ensures that all holders of an interest in capturing oil or gas from a single pool have an opportunity to do so.

- $\quad$ The rule of capture may be supplanted by legislation that attaches property rights to petroleum that remain through production.

- The effects of the rule of capture may be moderated by legislation that ensures that a holder of an interest in oil or gas is not left to suffer ongoing drainage as a result of inability to access transportation, processing, or markets.

- The rule of capture may be modified by specific agreement between parties and by implied terms in instruments granting rights to the opportunity to capture oil and or gas.

- The rule of capture does not apply across phase changes of petroleum substances.

- The rule of capture as recognized and relied on by regulators is the traditional rule.

- $\quad$ Regulators rely on the rule of capture to provide an incentive to encourage exploration and drilling activity. 
- $\quad$ Finally, recent Canadian case law ${ }^{145}$ indicates that where supported by industry practice or by legislative intent, the strict application of the rule of capture may be circumscribed by equitable principles and by the balancing of parties' legitimate expectations in regards to risk/reward.

\section{CONCLUSION: ISSUES TO CONSIDER}

In the oil and gas context in Canada, the common law rule of capture serves several functions. First, where parties hold rights to different resources in the same lands, the rule of capture serves as the default position when allocating parties' entitlements in a situation where the reasonable exercise of rights held by one party unavoidably interferes with rights held by another, where the latter party has not invested in the exercise of his rights.

Second, in the regulatory context, the rule of capture functions within a framework of conservation legislation that takes into account correlative rights and provides parties with a level playing field for the purposes of competing for a fair share of production. In that context it addresses the situation where a party who is in compliance with all relevant conservation provisions has nonetheless captured oil or gas from under lands to which it does not have rights. As a result, in the overall framework of the regulatory regimes established for oil and gas exploration and development in Canada, the rule of capture serves a useful purpose. It completes the allocation of rights to oil and gas actually produced in a manner that fills any gaps left by the conservation framework and avoids difficult, if not impossible, issues of proof. ${ }^{146}$

In the split title context, however, the common law rule of capture as implicitly relied on is a misplaced rule of convenience. To the extent that competing interests in gas/oil/bitumen production are not addressed through concurrent production schemes provided for in conservation legislation, ${ }^{147}$ as the same issues of proof do not arise, there is no reason why compensation or an accounting for gas incidentally produced could not be required.

Different issues are raised by the application of the traditional rule of capture to adjacent lands. For example, consider an oil or gas pool that extends from provincial lands to National Park lands or other lands that are closed to resource development for conservation purposes. ${ }^{148}$ Is it in the public interest for oil and gas to be produced from beneath the protected lands through a cluster of wells along the park boundary? ${ }^{149}$ To the extent that the overall public benefits from such oil and gas production outweigh the costs, including societal costs, then perhaps it is appropriate for the rule of capture to facilitate such activity;

Lickacz, supra note 65 and Goodwell, supra note 69.

For example, proof of which molecule of oil or gas came from under which lands.

See e.g. Alberta Conservation Act, supra note 83, s. 39(1)(f); Drilling and Production Regulation, B.C. Reg. 362/98, s. 88.

Clearly, the answer depends on the specific circumstances. For example, if the park lands are federal Crown lands in which the federal Crown owns the mineral rights, then the answer may be different if the lands were transferred from the relevant province and in which the province retained an interest in the minerals.

For a graphic example of this see online: Shell <http://www.shell.ca/home/content/ca-en/about_shell/ what_we_do/exploration_production/waterton/region/waterton_castle_sd.html > showing wells tightly clustered along the northeast boundary of Waterton National Park. 
however, questions such as which Crown is entitled to royalties in respect of the oil and gas produced merit consideration. ${ }^{150}$

Similarly, the more traditional line of cases, Placid Oil in particular, raises an interesting question. Pursuant to comprehensive land claim settlements, some First Nations have been granted the fee simple interest in minerals, including oil and gas, in certain lands, (Category A Lands) ${ }^{151}$ If appropriately worded legislation can attach ownership rights to oil and gas in place that remain through production regardless of who produced the petroleum, is it possible that comprehensive land claim settlement legislation transferring to First Nations the fee simple interest in minerals under their lands attaches sufficient ownership interest in that oil and gas that it may not be subject to the rule of capture? To put it another way, if Xco drilled a well thereby discovering an oil pool on frontier lands ${ }^{152}$ that extended to a First Nation's Category A Lands, could Xco simply produce as much of the oil as it could from its well and deal with it as it sees fit, or would the First Nation or a person who holds oil and gas rights from the First Nation on the relevant Category A lands be able to obtain an injunction preventing production of their share of oil from the pool? The answer to this question is beyond the scope of this paper but in light of increasing success in oil and gas exploration in the Territories and the proximity of some more recent discoveries to First Nation comprehensive settlement lands, it merits consideration.

Finally, what about the situation where an oil and gas pool extends from one jurisdiction into another? ${ }^{153}$ At one level, since, in most cases in Western Canada, oil and gas rights are owned by the Crown, there is no capture, in terms of ownership, across a provincial or territorial boundary ${ }^{154}$ If both jurisdictions have well established spacing and production requirements in their conservation legislation, then the issue may not be significant in terms of the potential for actual capture. However, if the situation were such that the adjacent jurisdictions had very different surface access, conservation, or fiscal regimes so that it was more advantageous to operate in one than the other, is it appropriate for Xco to be able to exploit oil and gas resources in one jurisdiction from another? Should parties with interests in a pool that extends across a provincial or territorial boundary not be able to pool or unitize across the boundary with the sanction of the relevant regulators to minimize cross-boundary capture?

This is currently an issue in Alaska where there is concern about the effects of the rule of capture on oil produced from under Alaska National Wildlife Refuge lands by wells drilled from outside those lands. See Kristen Nelson, Rule of Capture Prevails, online: PNA News < www.anwr.org/features/capture. htm>, last accessed March 2008.

See Gwich'in Comprehensive Land Claim Agreement, Canada and the Gwich'in, 22 April 1992, online: Gwich'in Tribal Council <http://www.gwichin.nt.ca/LCA>, art. 18.1.2b. The settlement was given effect in Gwich'in Land Claim Settlement Act, S.C. 1992, c. 53.

Frontier lands are defined in Canada Petroleum Resources Act, supra note 105, s. 2: "lands that belong to Her Majesty in right of Canada, or in respect of which Her Majesty in Right of Canada has the right to dispose of or exploit the natural resources, and that are situated in the Northwest Territories....” For example, natural gas pools in the Liard basin that extend from the Yukon Territory into the Northwest Territories or oil pools in the Lloydminster region that extend from Saskatchewan into Alberta, and, although additional and different considerations would apply, pools that extend from southern Saskatchewan or Manitoba into the northern U.S.

154 Since the Crown is considered indivisible for the purposes of natural resource ownership - as opposed to management and ability to legislate. 
The vast majority of hydrocarbons in Canada are a public resource. They are "owned” by the Crown and managed and developed for the public benefit. Does the rule of capture support this end? For the most part, as a part of a well-developed conservation scheme that takes into account correlative rights, it does. However, policy-makers would do well to consider whether that is true in all situations. 